\title{
Objectives and means in Finnish agricultural policy
}

\author{
LAURI KETTUNEN
}

Agricultural Economics Research Institute, Rukkila, 00410 Helsinki 41

\begin{abstract}
The aims of the Finnish agricultural policy are to safeguard agricultural self-sufficiency and the evolution of farmers' income, to develop the structure of agriculture and to try to maintain the rural population. Price and income policy, production policy, structural policy and regional policy are applied to reach these objectives. The application is hampered partly by their contradictory effects.

The most important instrument in Finnish agricultural policy has been the price policy. It has been based on price Acts, which have given general guidelines on the price level. In recent years, however, measures restricting production have become dominant in agricultural policy.
\end{abstract}

\section{Introduction}

Finnish agricultural policy was very strongly affected by World War II and subsequent experiences. At the time there was a food shortage so it is understandable that self-sufficiency under all circumstances became the first goal for agriculture. This meant that production had to be increased in many different ways. New farms were founded and more fields cleared, the country having just lost one-tenth of its field area. Technology was brought into agriculture and the use of inputs, above all fertilizers, became more efficient.

Self-sufficiency was achieved during the years after the war. Production recovered and as early as in the 1950's the country could start the export of milk products. For the first time, the concept of surplus entered the vocabulary of agricultural economists. At the same time, however, the basis of self-sufficiency was undermined by economic growth and increasing international division of labour. Even though production grew and the rate of self-sufficiency in final production rose, agriculture became more dependent on imported inputs. No doubt energy is the most vital and crucial of these.

The current agricultural policy can also be viewed in the light of the general economic and social development. Agriculture is the foundation for rural population. The farms are, however, small on average giving insufficient earnings. At the same time, the opportunities for an extra income have decreased. Hoping to achieve a higher standard of living a substantial part of the farm population, above all their children, have moved to centres of population or have left he country. This development cannot be regarded as sound. As the population left behind in the 
countryside decreases and gets older, the ability of the countryside to function grows weaker, which for its part makes it hard for those who have remained in the country to carry on farming. In this situation different goals come into conflict because of agricultural surpluses. Production of milk, eggs and meat exceeds domestic consumption, and world market prices are usually substantially lower than producer prices. Exports must therefore be subsidised with state funds to prevent the producer prices from falling under the target prices. The state budget, however, sets its own limits on export premiums, which, again, creates pressure to curtail production. This stands in contradiction with the attempts to maintain the quantity of the agricultural population, and to raise productivity and the level of income.

\section{Goals of agricuitural policy}

The above should be kept in mind when studying Finnish agricultural policy. It has been formed by practical experience and consists of activities of a great variety. It does not always follow a clear line of argument as there is no general agricultural programme that has been officially approved.

The following goals for agricultural policy can, however, be derived from the statements in the proposal for the state budget, in the reports of various committees and commissions (ANON. 1980b and 1980c):

- self-sufficiency in food commodities

- safeguarding and developing the income level of the farmers while maintaining the retail prices of agricultural products at a reasonable level

- developing the structure of agriculture

- maintaining the rural population

The goals are universal, they can be found in the policy declarations of many other industrial countries. However, they carry a different significance in each country, so they must be studied in greater detail.

\subsection{The goal of self-sufficiency}

As stated above, an increase in production became the main task of agricultural policy after World War II. New farms had to be found for front-line soldiers as well as for the evacuees. Therefore new fields had to be cleared. The total field area increased until the end of the 1960's. Even though total production grew, selfsufficiency in bread grains was not achieved until the 1960's. On the other hand, milk production exceeded the domestic need as early as in the 1950's. At this time, the first signs of warning against over-production could also be seen. Butter has often been a problem in agriculture. When exports of butter to England ceased at the end of the 1960's because of the EEC-agreements, strong measures to restrict production had to be resorted to. The soil bank system and the slaughtering scheme of dairy cows are among these. Today, the self-sufficiency goal involves restrictions on output.

A committee under the leadership of Dr. Samuli Suomela, general manager of 
Table 1. Self-sufficiency in certain products in 1950-80.

\begin{tabular}{lrrrrrrr}
\hline & $1950-54$ & $1955-59$ & $1960-64$ & $1965-69$ & $1970-74$ & $1975-79$ & 1980 \\
\cline { 2 - 8 } Milk & 102 & 120 & 117 & 118 & 124 & 126 & 127 \\
Pork & 102 & 100 & 99 & 106 & 115 & 110 & 116 \\
Beef & 100 & 100 & 97 & 101 & 106 & 101 & 106 \\
Eggs & 101 & 114 & 124 & 129 & 148 & 152 & 140 \\
Rye & 63 & 57 & 70 & 85 & 101 & 83 & 98 \\
Wheat & 48 & 41 & 80 & 101 & 129 & 92 & 89 \\
\hline
\end{tabular}

the National Board of Agriculture, proposed at the beginning of the 1970's that the production target for animal products should be set at $105 \%$ of the self-sufficiency level and for bread grains at $100 \%$ (ANON. 1969). The proposed figures for the proportion of self sufficiency in sugar and oil seeds were $40 \%$ and $20 \%$ respectively. Some years later a new committee was established to revise these figures. This committee, under the leadership of Mr. Reino Uronen, permanent secretary of the Ministry of Agriculture and Forestry, rejected the goals as being too low. His group did not, however, state any precise figures to be aimed at except for milk, the proportion of which was set at $115 \%$ of the self-sufficiency level (ANON. $1980 \mathrm{~b}$ ). As to other production, it was the principle of the committee to try to keep the present acreage cultivated and to control supply by fallowing. On the representation of the committee, short term objects, so-called production ceilings, were created, which have been applied in the past few years.

At present, the aim of self-sufficiency in general signifies balanced production and consumption though it can be seen that a small surplus is allowed. As to separate products, lower self-sufficiency in e.g. milk and eggs and higher production of bread grains and oil seeds are desired. It will probably be necessary to import protein feed to some extent also in the future, though the country is by now not far from selfsufficiency in this respect. It seems that fruits, vegetables and sugar will remain the only products unable to reach self-sufficiency.

\subsection{Farm income level}

According to various research works and statistics, farm income is clearly lower than the average for the whole economy (IHAMUOTILA 1979). Farm income development has been controlled by farm price acts since 1956. However, they have not included any explicit and definite farm income recommendations. On the other hand, the general goal has been - though not stated precisely - to develop farm income on the lines of incomes in other sectors of the economy. The latest applied price act has, however, in a way admitted higher percentages because the act has not specified any rules for allowed increases.

The goals for farm income level and for self-sufficiency are difficult to harmonize because it is not possible to increase production though this would be necessary e.g. for a larger farm size and income. 


\subsection{Structural development}

Farm sizes in Finland continue to be small, about 12 hectares on average. This is generally too little to support a family. Because there are not always opportunities for extra earnings outside agriculture it is vital to enlarge the farm sizes. This is one of the main goals of structural policy. In this way the capacity of the surviving farms would also be increased. Structural policy is generally concerned with increased productivity and complies thus with the goals of income policy. Productivity and efficiency have not received much emphasis in Finnish agricultural policy though they are included in the goals at least implicitly. There have even been warnings against high efficiency as it may lead to accelerated decreases in the rural population.

\subsection{Maintaining rural population}

Recently, more and more emphasis has been laid on the importance of agriculture in maintaining the population. Rural desolation results in many social problems. Schools, shops, health centres, etc. will find it harder to offer services when they lose customers. Therefore, the goal has been set that neither the number of farms nor the agricultural labour force should decline from the present level (ANON. 1980b). This in turn, will naturally put restrictions on the structural development of agriculture.

This goal is unusual in a country's agricultural policy and may rather be regarded as a social measure. The goal is problematic in the sense that it impedes the development of agriculture in other respects, e.g. with structural rationalization.

\section{The means of agricultural policy}

There are different instruments for different goals. It is not easy to name the range of individual instruments in accordance with the various goals, so the following classes of agricultural policy are dealt with in the following pages (IHAMUOTILA 1979, ANON. 1979 and 1980a):

- price and income policy

- production policy

- structural policy

- regional policy

It should be stated briefly that various instruments have several influences. Price policy affects the production policy in addition to income policy, production policy affects also the income policy and structural policy affects production and income policies.

\subsection{Price and income policy}

Price policy plays a major role in our agricultural policy. It attempts, above all, to safeguard the development of farm income, but simultaneously it controls the 
development of both producer and consumer prices. In fact, well balanced prices are an object of the Finnish agricultural policy, whereas the income level is allowed to change along with the production. To some extent, however, supply affects the prices, but the range of the fluctuations has been restricted.

The price policy is based on agricultural income acts (price acts) which have been passed since 1956 (IHAMUOTILA 1979). The price law gives directions which control producer prices. It is used as the basis when the so-called target prices for the major products (milk, pork, beef, mutton, eggs, rye, wheat, feed barley and feed oats) are set. The target prices are now revised twice a year in negotiations between the government and the producers' organizations. The new target prices become effective at the beginning of March and Septembei, for cereals, however, usually at the beginning of August (HEMILÄ 1980, KETTUNEN 1981).

There are two stages in the negotiation process. At the first stage, the deviation between the present level of the price of producers' inputs and the level of the preceding decision is calculated. The increases in costs (a decrease has not been heard of for a long time!) are fully compensated to farmers. At the second stage, the raising of farm income - or the compensation for farm labour input and for the capital owned by the farmer - form a subject for negotiations. The negotiators are now free to decide on this rise; the only directive for them is the general agreement that farmers should be able to share in the general rise of the standard of living. In earlier years the development of farm income was linked for example with the general wage level index (the 1962-64 price act) or the wage level index of farm workers (the 1972-74 price act).

In the price negotiations the parties first decide on the average rise in costs. Thereafter the increase is compensated in different target price products. In this connection, the price policy can be used as an instrument of production policy by changing the price relations. In practice there have been several cases when the price of a product (recently the price of wheat and rye) has been raised sharply to stimulate production.

To bring the actual producer price in line with the target price (or as close to it as possible), the government regulates the price formation in many ways. The maximum retail prices for milk and cereal products are confirmed by the Board of Consumer Interests. When these prices are fixed, changes in the collection, processing and retail costs are taken into consideration so that farmers can be paid in accordance with the target price. The prices of some processed meat products are also regulated. The prices of meat and eggs are free to fluctuate, but the government regulates the supply by granting export and/or import licenses. In case the producer price declines too much, exports will be allowed which result in lower supply and higher prices. Too high a producer price can be lowered with the help of imports (KETTUNEN 1980a).

Export subsidy is an essential part of the price policy. To prevent producer prices from falling below the target price, the difference between the target price and the export price is paid to agriculture (export firms are usually co-operatives and thus generally owned by the farmers). Correspondingly, imported products pay import duty. In connection with imports of cereals, sugar and oil seeds, a two-price system is applied, which means an adjustment between the higher domestic price and the lower world market prices. 
The price law system is closely attached to the price support, which is paid by region and by size of farm. For equal pay to farmers price support is given in the following forms (HANHILAHTI 1980):

- extra price for milk

- according to the number of milking cows

- subsidy for meat production

- production fee for rye

- price allowance of feed bought

- milk transportion subsidy

- regional acreage support

Of these, the area support is a general equalization which covers the whole country. It is paid to small farms and becomes higher towards the north.

\section{Production policy}

The functional task of production policy is generally speaking to achieve the desired production goals to increase and/or control production. Controlling measures have partly been adopted also, in Finland, but for the most part production policy has meant restrictions on production. Supporting and restricting measures are examined separately in the following.

Measures to promote and support production:

- production fee $2.20 \mathrm{mk} / \mathrm{kg}$ for beef cattle over $210 \mathrm{~kg}, 1.30 \mathrm{mk} / \mathrm{kg}$ for carcass weight over $160 \mathrm{~kg}$

- production fee $2.20 \mathrm{mk} / \mathrm{kg}$ for sheep cattle over $12 \mathrm{~kg}$ in carcass weight

Production of sugar and oil seed has been supported by rises in production prices.

However, production policy has above all concentrated on restrictions on supply. When exports encountered obstacles at the end of the 1960's, vigorous attempts were made to lower the production capacity. Even though the export difficulties later vanished, action continues to be taken to avoid over-production for state budgetary reasons. Below are some of the supply control measures (KETTUNEN 1980b):

- the soil bank system

- fallowing scheme

- slaughtering fees for cows and hens

- restrictions on hatcheries

- restrictions on large-scale animal production

- production ceilings

- marketing fees

Of these, the soil bank system together with the fallowing scheme have had the clearest effect on production, since animal production in Finland is based mainly on domestic feed. The rest of the measures control production rather than restrict it, though their restrictive effect must not be under-estimated. However, it can be assumed that e.g. the slaughtering of cows will leave more feed e.g. to increase pork production. Likewise restrictions on hatcheries have caused lower egg production, though again more feed can be used for other purposes, e.g. pork. It appears that restrictions on egg production encourage the pork output. 
The restrictions on large-scale animal production are partly aimed at curbing the output, but at the same time it is hoped to prevent agriculture from reaching production on an industrial scale, and to provide incentives for family farming.

The production ceilings included in the price act can regulate production only product by product. However, farmers do not have much chance to switch to other products as there is a surplus of all the main products. Measures of supply control also work for a balanced output. Among these are:

- contracts for changing line of production

- special beef scheme

- contract farming

A contract for changing the line of production means that compensation is paid to farmers who switch from milk production to other products. Crop or beef production are recommended instead. The amount of compensation depends on the farmer's income from milk.

The special beef scheme, too, was adopted to curb the surplus milk production and to increase beef production, which depends on the number of milking cows for the time being. A compensation is paid to the farmer if he raises stock for beef production without selling any milk on the market. This system was started in 1980.

Contract farming is applied, for example, to sugar-beet, oil seed, partly to potatoes, vegetables and berries, malting barley and broiler production. These contracts control output quite effectively in the desired direction (ANON. 1975).

\section{Structural policy}

The objective of structural policy is to help achieve the production goals, to develop agriculture as a whole in line with the general social development, and to meet with the requirements of the population in the country. Structural policy includes objectives to improve the viability of agriculture, to enlarge the farm size, and to increase productivity (ANON. 1980c). Aims at higher productivity and efficiency conflict, of course, with the efforts to prevent rural depopulation, but it appears that a larger farm size remains the primary goal.

In Finland, structural policy is carried out mainly under the Farm Act. It defines the provisions for acquiring land or enlarging a farm unit. The present policy favours the establishment of larger than average farms. For reasons of regional policy, state loans are directed to the agriculturally less advantageous regions in the northern and eastern parts of the country but interest-subsidised loans are available in southern Finland, where there is the best arable land.

In this connection it should be recalled that the creation of large scale production units is subject to permission from the Board of Agriculture. In a way this regulates the agricultural production structure because to obtain permission to establish large animal farms is quite difficult. At the same time it retards specialization to some extent, because the farmer may have to start producing pork or eggs, for example, as the permission limits may prevent production specialization in just one product.

Specialization and a decreasing farm population and farm numbers are typical features of structural development. It is extremely hard to influence these, and so structural policy can only partly control the development. 


\section{Summary and conclusions}

There are no official, binding decisions covering the whole of Finnish agricultural policy. Neither can it be claimed that it totally lacks principles. For example, Agricultural Income Acts have controlled price policy since 1956 and in that connection other sectors of agricultural policy, e.g. production policy, have been considered as well. The lack of a concise policy is realized however, and at present a parliamentary commission is drawing up a long-term programme for agricultural policy.

On the basis of the proposal for the state budget, the presentations of various committees and commissions and the policy in practice, it can be stated that the objectives of Finnish agricultural policy are:

- to safeguard agricultural self-sufficiency

- to safeguard the evolution of farmers' income at the same time as the retail prices of agricultural products are kept at a reasonable level

- to develop the structure of agriculture

- to try to maintain the rural population

The objectives form a unity, parts of which generally support each other, although they may sometimes be contradictory to each other, e.g. development of structure and maintaining the population are hard to match.

There are several measures to reach these objectives. They can be classified in the following way:

- price and income policy

- production policy

- structural policy

- regional policy

Also the measures form a unity, parts of which support and complement each other. Price policy is used to support production and structural policy, production policy supports income policy, structural policy supports regional policy, etc. The effects of the measures may also be contradictory in some respect. Structural policy leads most often to larger farms, which usually conflicts with the efforts to prevent depopulation.

The most important instrument in the Finnish agricultural policy has been price policy. It has been based on price laws, which have given general guidelines on price levels. It has been the main means to control the development of farmers' income level, while at the same time it has been possible to practice production control to some extent.

In recent years, however, measures restricting production have become dominant in agricultural policy. Several means have been used to restrict the overproduction of animal products. The soil-bank system, the fallowing scheme, slaughtering fees for cows and hens, production ceilings, marketing fees, etc. are among these. These measures have not appealed to the farmers, but no other solution has been found to reduce the surplus.

Structural policy is, however, becoming a more and more central sector in agricultural policy, e.g. rural depopulation and desolation, problems of an aging farm population, the hardship of generation changes, capital problems, etc. 
contribute to this. With regard to these matters it has even been claimed that without strong structural policy measures the self-sufficiency of our agriculture is in danger.

Finnish agricultural policy may perhaps be characterized as slightly contradictory. On the one hand, self-sufficiency is strongly emphasized, while on the other hand, agricultural policy is in practice directed more towards restricting production. To raise the income level, productivity should be improved, but from the point of view of employment and regional policy, the agricultural population should be kept at the present level, which of course, conflicts with the productivity and efficiency goals. General social and party-political objectives tend to mix with proper agricultural policy, which, of course, makes things more difficult. It appears, however, that these kinds of conflicts in agricultural policy do not apply only in Finland since the problem is shared by several other industrial countries.

\title{
References
}

ANON. 1975. Agricultural policy in Finland. OECD. 51 p. Paris.

- 1969. Maatalouskomitean mietintö III. Kom. miet. 1969 B:40. 27 p. Helsinki.

- 1980a. Review of agricultural policies in OECD member countries 1979. OECD. 116 p. Paris.

- 1980b. Maatalouden tuotantopoliittisen toimikunnan osamietintō II. Kom. miet. 1980:5. $149+4$ p. Helsinki.

- 1980c. Maatalouden rakennepoliittisen toimikunnan mietintö. Kom. miet. 1980:9. $164+29$ p. Helsinki. HANHILAHTI, H. 1980. Subsidies in Finnish agricultural policy. Agric. Econ. Res. Inst., Publ. 43: 19-31. Helsinki.

HEMILÄ, K. 1980. Characteristics and main goals of agricultural price policy in Finland. Agric. Econ. Res. Inst., Publ. 43: 1-18. Helsinki.

IHAMUOTILA, R. 1979. Maatalouden hinta- ja tulopolitiikka. 156 p. Helsinki.

KETTUNEN, L. 1980a. Administered price formation of agricultural products and the use of computer models in Finland. Agric. Econ. Res. Inst., Publ. 43:54-65. Helsinki.

- 1980b. Finnish agriculture in 1979. Agric. Econ. Res. Inst., Res. rep. 61a. 26 p. Helsinki.

- 1981. Finnish agriculture in 1980. Agric. Econ. Res. Inst., Res. rep. 74a. 31 p. Helsinki.

Ms received October 23, 1981

\section{SELOSTUS}

\section{Suomen maatalouspolitiikan tavoitteet ja keinot}

\author{
Lauri Kettunen
}

Maatalouden taloudellinen tutkimuslaitos, Rukkila, 00410 Helsinki 41

Suomen maatalouden tavoitteita ovat elintarvikkeiden omavaraisuus, viljelijöiden tulotason turvaaminen, maatalouden rakenteen kehittäminen ja maaseudun asutuksen säilyttäminen. Näiden tavoitteiden saavuttamiseksi käytetään hinta- ja tulopolitiikkaa, tuotantopolitiikkaa, rakennepolitiikkaa ja aluepolitiikkaa. Eri keinojen käyttämistä vaikeuttavat osittain niiden vastakkaiset vaikutukset.

Tärkein maatalouspolitiikan väline on ollut hintapolitiikka. Se on perustunut hintalakeihin, jotka ovat antaneet yleisohjeet hintatason määrittämiseen. Viime vuosina on kuitenkin tuotantopolitiikka tullut yhä keskeisemmäksi maatalouspolitiikan kohteeksi. Käytännössä se on merkinnyt erilaisia tuotannon rajoitustoimia. 